モノニ於デモ皆 1 居〉內农細胞棁扁平上皮 7 以 テ被ハル。尚ホ上皮下組織ハ多クハ繊細粗矮ナ ル結締織ガ蜂笨/發育狀態ニヨリ種アナル厚サ ヨ示シ. 其中二存スル血管，狀態モ亦之ト同樣 二種タナル美異 層が周園ノ骨質二接シ居レドモ此骨質八䗋笨發 育可良ナルモノニ於テ八歐氏管周園.鼓室天㦈. 乳嘴突起ノ部ニ於テ著明ナル侵蝕作用ラ被ムリ 殊=鼓室天蓋及ビ其附近，䗋窠＝於テ著明 =シ テ數例二於テハ鼓室或八䗋笨粘膜卜硬腦膜トが 結䋨織 其他種々興味アル所見ヨ得タルラ以テ之ヨ䐂述 シ.最後二是等種々ナル發育狀態 鼓室竝二歐氏管等ノ粘膜，狀態卜蜂家發育卜， 關係等 $=$ 關シ先人ノ諸說卜比较考察シテ早見 7 遬ペントス。

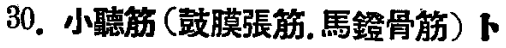

㪗膜幻燈使用

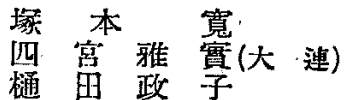

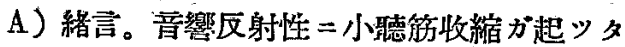
時, 鼓膜ノ態度二關シテハ. 一般二屍䯣標本 = 於ヶル所見卜同樣二.内方二陷洺スルモ，卜看 做サレテキルガ(ヘンゼン, ハンマーシュラー

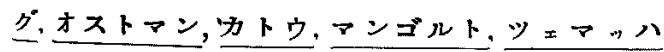
等. 他方鼓膜八殆ンド不動デ有ルト稱へル人タ 分有ル (ワアル,ルッシュル, コブラック等)。私

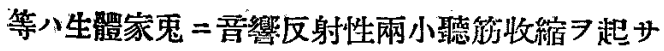
セ公場合，1) 果シテ鼓膜ハ內方二陷沟スルカ 态カ. 2) 若シ鼓膜が內方二陷滠スル時二八其 程度へ如何程デァルカ. 驗 ア企テタ。

B）實驗方法。內腔横斷面積 0.26 平方 $\mathrm{mm}$ ，

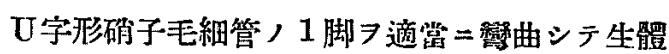
家鬼, 右側中耳骨球/下壁 7 贀1テ中耳腔内 = 雨入シ。毛細管卜骨球下壁卜八松脂。落科用「七 メント」デ固定スル。毛細管U字部二極微少，

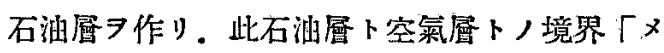
ニスクス」ノ移動ワ適當ノ光源. 掂大「レンズ」 等ヨ使用シテ光學的「キモグラフィオン」ノ感

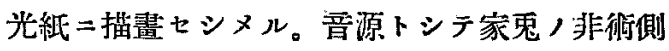

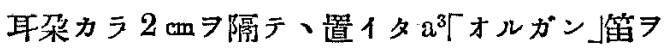
$7.5 \mathrm{~mm}$ 水杜氣壓ブ鳴ラシタ畐響フ用七. 其鳴笛 壓ヨ同特ニマレイ氏代カプセル」デ描書サセル。

C）實駱例泣＝實驗成績。

1) 第 1 家鬼(昭和 10 年 10 月 23 日). 輕度 「ウレタン」述醉使用.「メシスクス」移動ノ光學 的擴大率 66.3倍. 䆵驗成積 (1) 鼓膜緊張部，

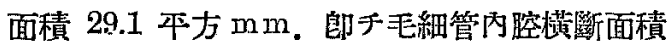
ノ約 112 倍。(口)輕度「ウレタン」麻醉時， 音 響性兩小聽節反射二基ク「メニスクス」移動， 大イサ八. 最大 $0.33 \mathrm{~mm}$. 最小 $0.06 \mathrm{~mm}$. 平均

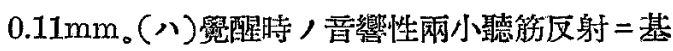
ク「メニスクス」移動ノ大イサハ. 最大 $0.98 \mathrm{~mm}$. 最小 $0.27 \mathrm{~mm}$. 平均 $0.61 \mathrm{~mm}$ 。

2 ) 第 2 家鬼(昭和 10 年 11 月 2 日).輕廣「门 レタン」磨醉使用.「メ=スクス」移動ノ光學的 擴大率 63.1倍。實驗成績 (1)鼓膜緊張部)面 積 28.2 平方 $\mathrm{mm}$. 即于毛細管內腔横断面積ノ約 108 倍.（ロ）輕度「ウレタン」底醉時，豆響性兩

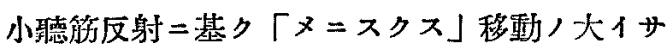

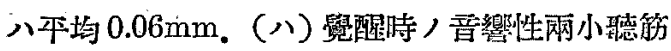
反射二基ク「メニスクス」移動ノ大イサ八 最 大 $0.69 \mathrm{~mm}$ 。最小 $0.17 \mathrm{~mm}$ 。平均 $0.69 \mathrm{~mm}$ 。

第 1 家鬼. 第 2 家鬼兩者デ八其中耳毛細管U 字部, 石油屡八畐響刺钱 $=ヨ$ リ常 $=$ 外方 $=$ 移動 $12-55$ 
スル。郎チ鼓腅八內方二陷沒スル。

D) 考事項。1) $a^{3}\lceil$ 「オガン」笛 77.5mm

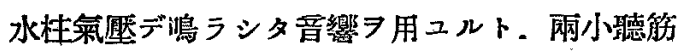

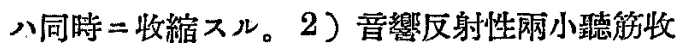
縮ノ際ニ八歐氏管八開カナ1。3）吾響反射性 网小聽筋收縮 $=$ 基り鼓膜，内方陷沟 $=\Xi$ リ．中 耳毛細管U字部ノ極徽石油層が外方二移動スル 場合．多少トモ中耳內空㴋が原縮セラレ，從ツ テ鼓膜弛緩部が外方二移動ス儿事八否定出來ナ

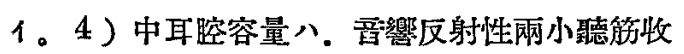

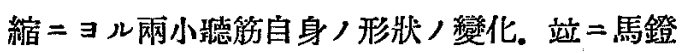
骨底板, 卵圓㝕内陷没等 $=ヨ リ$ 名ンド影響习受 ケナイ。5）畐響反射性兩小㯖筋收縮二基り鼓

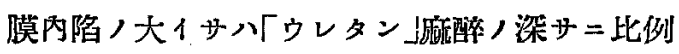

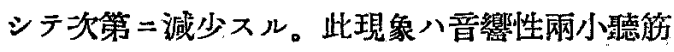
反射，興窗性ガ麻醉，雼二低下スル故デ有ル。

6 ）曋響反射性兩小聽筋收縮八鼓膜=對スルョ リモ。駼鐙骨底板. 饮チ內耳二對シテ ヨリ大 ナル影響习與へル。7) 音響反射性馬鐙骨筇收 縮ノ鼓膜二對スル影響，研究ハ十分二出來ナカ ツタ。

E) 結論。生體家鬼二適當ナ畐響刺㦸 7 與一 テ 兩小聽筋ノ收縮 7 惹起サセタトキ次ノ事實 ガ證明デキタ。

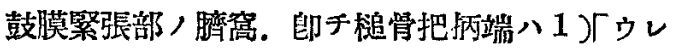
タン」輕度廂醉時ニ八平均シテ少ナクトモ第 1 家鬼デハ $1.8 \mu$ 。第 2 家航デハ $1.0 \mu 2$ ）覺醒 時ニハ平均シテ少ナクトモ第 1 家鬼デハ $11.2 \mu$ 第 2 家雭デハ7.4 シナケレバナラナイ。

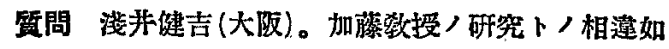
何。

\section{1. 耳性頭䍌内合併症ニ於ケル「マス}

チャクス」反應ノ成樍二就テ

三原彬茂

昨年 1 月 $コ$ 約 1 ケ年筑二於ケル大阪赤十字 病院耳鼻科大院患者中. 頭蓋內合併症习思ハシ ムル症候 ゲマシタ樣ナ諸種り检索フ施行致シマシタル 所. 其內「マスチっタス」反應二就テ特二與味

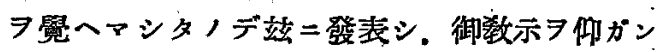
トスル次第デアリマス。

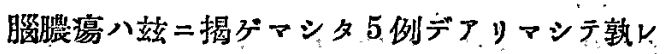
モ特異ナル腦膿瘍曲線ヨ得マシタ(圖・見セル) 清川(第 1 例)八例八淿二一部發表シマシタル如 ク . 臨牀上全然無症候二經過シ他ノリコール」 ノ所見モ. 此通り尋常デアリナシタノ二獨り 「マスチ・クス」反應ノミ特異ナル腅膿婸曲線 ア得. 手術ニヨリ其存在 7 確證シタノデアリマ

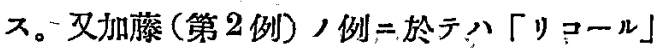
ノ液壓. 細胞數. 糖量. 蛋白量.「グロブทン」 反應等八化膿性腦膜炎, 所見 7 呈シ. 且兴㗐林 上=於テモ化毞性腰膜炎トヨリ外二考へラレナ カッタノデアリマスガ. 本反應ヨ見ルニ及ビ腲

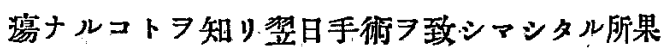
シテ頙雪葉葉膿瘍フ證明シ. 診斷上参考トナル所 大デアリマシタ。

次二耳性腦膜炎八此表二示ス 14 例デアりマシ テ. 第 1 、第 8 。第 9 、第 10 。第 11 . 第 12 . 第 13. 第 14. 青木. 大內. 丸岡. 松浪。燒野。堂 下. 田村. 大森. 扣藤某ノ 9 例八敦レも此表 如 + 定型的化膿性胋膜炎型 7 呈シ。郎手約 $64 \%$ ノ陽性率 7 示シ. 久保. 山上. 吉川. 谷澤某, 4 例八此表/如キ不定型曲線习示ス。残り/1 例(吉原)八陰性デアッタノデアリマス。全例卜 